\title{
Nick Piška*
}

\section{Equity and the Resources of Critique: Part II}

The idiom of 'equity' provides potential and possibility for imaginative, progressive critical engagement in historical and contemporary political, economic and juridical thought, policy and practice. The frequent, urgent demand for 'equity' - whether in terms of gender, race, class, or intergenerational equality - alongside the more usual calls for justice signals this. But in addition to admirable qualities such as equality and justice equity is also associated with more questionable political and economic concepts and practices: exceptionalism, sovereignty and absolutism, and with the architecture and governance of financial capitalism. ${ }^{1}$ The introduction to Part One of this Focus on 'equity and the resources of critique' (in the previous issue of Polemos ${ }^{2}$ ) introduced some of the problems with a Focus on 'equity', in particular that there are many different surfaces to this conceptual multiverse. I highlighted three surfaces which, when folded together, constitute an equitable assemblage concerned with judgement, jurisdiction and wealth. Part One emphasised questions of judgment and jurisdiction and the office of jurist. Part Two turns towards property and wealth, moving further into the heart of contemporary practices of equity (particularly the equity of the English Chancery jurisdiction) and their relation to capitalist economy. In this move into modernity - into the 'rational', positivist world with its rule of law - we can also identify the underside of legal reason and all that comes with it: alchemy, magic, irrationality and the unconscious.

While Part One ended, at the hinge of a diptych, with Maitland's body and the theme of burial, this part opens at the other side of the hinge, with another body and the problem of burial: that of Antigone's body and the problem of law and justice as read through 'Aristotle's Pharmacy' (Piška). My contribution takes equity's remedial quality seriously through the framework of the pharmakon. Reading the history of equity through its mnemotechnics enables us to read equity's contributions to the constitution of law's memory. It argues that these mnemotechnics captured not only memories of the past but memories of the future, a condition of possibility for the rise of indebted man and financial capitalism.

Sarah Wilson, in her contribution, is also concerned with history and financial capitalism. She argues that an historical awareness can contribute to an understanding of social change and make possible alternative

\footnotetext{
* Corresponding author: Nick Piška, Kent Law School, University of Kent, UK, Email: n.piska@kent.ac.uk

${ }^{1}$ For a summary of the relation of equity to exceptionalism and sovereignty see P. Kahn, Political Theology: Four New Chapters on the Concept of Sovereignty (Columbia University Press, 2012). On equity and absolutism see, for example, T. Hobbes, A Dialogue Between a Philosopher and a Student of the Common Laws of England (ed. J. Cropsey, University of Chicago Press, 1997). On financial capitalism and wealth inequality see B. Harrington, Capital Without Borders: Wealth Managers and the One Percent (Harvard University Press, 2016).

2 Polemos 2016; 10(2).
} 
visions of the future following the financial crisis. The question of social change is a theme that returns in Geoffrey Samuel's and Adam Gearey's contributions. Samuel focuses on Chancery's form of legal reasoning and argues that far from being devoid of rationality, equity provides a means to escape from the binary logic of legal reason and a means of giving expression to 'social reality'; equitable remedies push law outwards from within factual situations and advance or develop law through the logic of the exception. Samuel, like my own contribution, observes that this enables the emergence of new forms of property, a point that Gearey develops in his critique of equity's role in financial capitalism. For Gearey, '[i]udicial engagement with changing social realities is central to equity's articulation of the movement of finance capital'. Gearey draws on Marxist and feminist works to demonstrate that the equitable assemblage plays an essential part in the social reproduction of financial capital and that the 'magic' of transforming money into more money (M-M1) is nothing more than a mystification in which equity is complicit whereby the risk of profit-making is shifted from financial institutions to domestic settings. Gearey argues that what is needed is 'an alternative equitable assemblage where capital is compelled to bear the costs of its own reproduction'. He ends on a hopeful note about the possibilities equity may provide in this regard: 'One can imagine all kinds of interesting ways in which equity might give recognition to the value of affective labour, and capital compelled to carry the real costs of its social reproduction.'

Matthew Stone takes up the possibilities and pitfalls of Gearey's suggestion. For Stone, standard conceptions of property tend not to elaborate a sense of responsibility due to a focus on individualism, but equitable property may provide a possibility for a different ethical quality of property. Drawing on Heidegger, Levinas and Derrida Stone develops a critique of the liberal rights bearing subject and suggests an alternative conception concerned with responsibility-vulnerability, a pairing which gives a primary role to notions of duty and conscience both in family setting but also commercial setting. ${ }^{3}$ While Gearey's critique ends on a note of hope, Stone ends on a note of caution: ' $\rceil \mathrm{t}$ is important not to get too mistyeyed about equity's ethical voice. Even if rooting obligations in duty, equity still allows for property to be delineated and allocated as a wealth asset.' Property and duty are also central to Robert Herian's contribution which draws on Freud and Lacan to develop an understanding of the trust, and in particular breach of trust, through psychoanalysis. Unlike traditional trust texts which focus on the consequences of breach of trust, Herian is more concerned with why breach occurs. In this regard he turns to the unconscious. Herian argues that the trust replicates the internal regulation of desire and enjoyment in order to channel the desires of trustees and beneficiaries: 'Trusts are engines for the creation and, ideally, the containment of desires.' This explains why the trustee must be subject to strict fiduciary obligations and

\footnotetext{
${ }^{3}$ An understanding of equity and equitable remedies as premised on the primacy of obligation can also be found in D. Hayton, 'The Development of Equity and the "Good Person" Philosophy in Common Law Systems' [2012] Conv 263.
} 
remedies for breach of trust - to appease 'temptation' where there is a possible conflict between interest and duty, and thereby maintain the trust as a legitimate capitalist form. ${ }^{4}$

Jan-Patrick Oppermann also draws on the work of psychoanalysis, but returns us to the philosophical concept of equity. Oppermann draws on Jean-Luc Nancy's concept of exscription and Kant's and Arendt's notions of the enlarged mentality and sensus communis to explore how we might conceive a broader understanding of judgment and justice, beyond a narrow legalism but also beyond our own experience or psyche, premised on the imagination and taking into account (the suffering of) the Other In this sense equity is concerned with an awareness of the unconscious, and hence the equitable judge is comparable to the analyst. The diptych closes with a return to Aristotle's equity. In contrast to Gary Watt's opening contribution in the first part of the Focus, which identifies 'true equity', Riccardo Baldissone's contribution argues for the recognition of a multiverse of equities and, moreover, keeping this multiverse open. Baldissone traces the historical formulations and settings of equity in relation to larger currents of Western thought. His is 'a plea for a coexisting plurality of legal equities', the conceptual multiverse being a shared space, producing a kind of cosmopolitanism of or for concepts.

This Focus has introduced a number of critical frameworks and theorists to the vast field of equity. Clearly further work is required, including feminist and gender critiques of equity - for example how the jurisprudence of equity is gendered - as well as colonial and postcolonial critiques. ${ }^{5}$ The articles collected in this Focus reinvigorate the work necessary for a critical engagement with equity as a protean, elusive, creative and possibly 'dangerous supplement'. One of the recurring themes in the Focus is that equity opens possibilities, that it holds potential, that it has an 'imaginative' aspect to it. How are we to understand and relate to these moments of hope that are held out for equity? As a form of nostalgia or utopianism? As a call for 'justice'? It is clear that equity cannot offer unproblematic solutions or answers to many - or even most - political, ethical and juridical impasses, but it does provide an assemblage of resources (an idiom; a mode of problematization; an array of practices) through which to frame alternatives. And the framing of ethical alternatives to contemporary political problems is - in light of the politics of at least the past year critical.

Nick Piška, University of Kent, UK

\footnotetext{
4 Also see I. Samet, 'Guarding the Fiduciary's Conscience-A Justification of a Stringent Profit-stripping Rule' (2008) 28(4) Oxford Journal of Legal Studies 763. For an alternative theoretical approach see I. Samet, 'Fiduciary Loyalty as Kantian Virtue' in A. Gold and P. Miller (eds), Philosophical Foundations of Fiduciary Law (Oxford University Press, 2014). ${ }^{5}$ For examples of feminist work on equity, see S. Scott-Hunt and H. Lim (eds), Feminist Perspectives on Equity \& Trusts (Cavendish Publishing, 2001). For examples of work on equity and postcolonialism, see K. Akuffo, 'Equity in Colonial West Africa - A Paradigm of Juridical Dislocation' (2006) 50(2) Journal of African Law 132 and 'A Subaltern Theory of Equity' (2016) 24(1) African Journal of International and Comparative Law 12.
} 
Version submitted to journal - for final version see Polemos (2017)

Author biography: Nick Piška is a Lecturer in Law at the University of Kent, UK. His research pursues a critical engagement with private law, particularly in the area of equity and trusts. He is currently writing a book on the fate of equity in modern law and society. He is the founding member with Rob Herian of the Equity \& Trusts Research Network (https://www.kent.ac.uk/law/research/centres-andgroups/equity.html) as well as a member of the advisory board of the University of Kent's transfaculty Centre for Critical Thought (https://www.kent.ac.uk/cct). He has previously been a researcher at the Law Commission for England and Wales. 